\title{
KARAKTERISTIK TROMBOSIT PADA PASIEN ANAK DENGAN INFEKSI VIRUS DENGUE DI MANADO
}

\author{
${ }^{1}$ Cindy Y. Motulo \\ ${ }^{2}$ Arthur E. Mongan \\ ${ }^{2}$ Maya F. Memah \\ ${ }^{1}$ Kandidat Skirpsi Fakultas Kedokteran Universitas Sam Ratulangi Manado \\ ${ }^{2}$ Bagian Patologi Klinik Universitas Sam Ratulangi Manado \\ Email: cymotulo@ymail.com
}

\begin{abstract}
Dengue virus infection is a global health problem since outbreaks have been reported in many countries. Children still occupy the top position in dengue infection. The information about dengue infection can help reduce the incidence of dengue infection. One of the laboratory tests that support the diagnosis is the platelet count. This study used a cross sectional design and was conducted from December 2014 until January 2015 at Robert Wolter Mongisidi Hospital, Advent Manado Hospital, and GMIM Pancaran Kasih Hospital. Samples were 37 patients who fulfilled the inclusion criteria. There were 17 males and 20 females. The results showed that 21 patients had thrombocytopenia meanwhile the others had thrombocyte count within normal limit. The PDW and the MPV were within normal limit.
\end{abstract}

Keywords: dengue, platelet count, PDW and MPV

\begin{abstract}
Abstrak: Infeksi virus dengue merupakan masalah kesehatan global. Kejadian luar biasa penyakit telah sering dilaporkan dari berbagai negara. Anak-anak masih menempati posis teratas dari kejadian infeksi dengue. Informasi tentang infeksi dengue dapat membantu mengurangi kejadian infeksi dengue. Banyak pemeriksaan laboratorium yang diperlukan, salah satunya ialah pemeriksaan trombosit. Penelitian ini menggunakan desain potong lintang, dan dilakukan pada bulan Desember 2014 sampai Januari 2015 di RSAD Robert Wolter Mongisidi, RS Advent Manado, dan RSU GMIM Pancaran Kasih Manado. Terdapat 37 pasien yang memenuhi kriteria penelitian, terdiri dari 17 laki-laki dan 20 perempuan. Hasil penelitian menunjukkan 21 pasien yang mengalami trombositopenia sedangkan 16 lainnya masih dalam batas normal. Nilai PDW dan MPV dalam batas normal.
\end{abstract}

Kata kunci: dengue, jumlah trombosit, PDW, MPV

Infeksi virus dengue merupakan masalah kesehatan global. Dalam tiga dekade ini terakhir terjadi peningkatan angka kejadian penyakit tersebut di berbagai negara. Kejadian luar biasa penyakit telah sering dilaporkan dari berbagai negara. Penyakit dengue terutama ditemukan di daerah tropis dan subtropis. ${ }^{1}$

Infeksi virus dengue menyebabkan penyakit dengan spektrum luas, di antaranya demam dengue (DD), demam berdarah dengue (DBD), dan sindrome syok dengue (SSD). Kasus terbanyak yang ditemukan ialah kasus DBD. ${ }^{2}$

Menurut data Dinas Kesehatan 2013 terdapat 410 kasus DBD di kota Manado pada tahun 2013, dengan insiden tertinggi di kecamatan Malalayang sebanyak 93 kasus, kecamatan Wanea 72 kasus, kecamatan Tikala 61 kasus, kecamatan 
Sario 50 kasus, kecamatan Singkil 43 kasus, kecamatan Mapanget 34 kasus, kecamatan Wenang 27 kasus, kecamatan Tuminting 24 kasus, dan kecamatan Bunaken 6 kasus.

Diagnosis DBD dapat ditegakkan antara lain dengan pemeriksaan laboratorium. Salah satu pemeriksaan laboratorium yang menunjang ialah pemeriksaan trombosit. Jumlah trombosit bisa turun sampai di bawah $100.000 / \mathrm{mm}^{3}$. Penurunan trombosit terjadi seiring dengan beratnya penyakit. Hitung trombosit dapat digunakan sebagai alat bantu untuk diagnosis dengue karena menunjukkan sensitivitas tinggi mulai dari hari ke-3 demam, bahkan pada hari ke-5 sampai ke$7 .^{3}$

Virus dengue termasuk genus Flavivirus (Arbovirus Grup B) salah satu dari Familia Togaviradae. Dikenal 4 serotype virus dengue, yaitu Den-1, Den-2, Den-3, dan Den-4. Virus Den-2 dan Den-3 secara bergantian merupakan serotype virus yang dominan, namun virus Den-3 sangat berkaitan dengan kasus DBD berat. Perbedaan klinis antara DD dan DBD disebabkan oleh mekanisme patofisiologi yang berbeda. Adanya renjatan pada DBD disebabkan oleh kebocoran plasma yang diduga diakibatkan oleh proses imunologi; hal ini tidak didapati pada DD. ${ }^{4}$

Virus Dengue yang masuk ke dalam tubuh akan beredar dalam sirkulasi darah dan ditangkap oleh makrofag. Viremia terjadi 2 hari sebelum timbul gejala hingga setelah lima hari terjadi demam. Antigen yang menempel pada makrofag akan mengaktifasi sel T-Helper dan menarik makrofag lainnya untuk menangkap lebih banyak virus. Sel T-helper akan mengaktifasi sel T-sitotoksik yang akan melisis makrofag. Telah dikenal 3 jenis antibodi yaitu antibodi netralisasi, antibodi hemaglutinasi, dan antibodi fiksasi komplemen. Proses ini akan diikuti dengan dilepaskannya mediator-mediator yang merangsang terjadinya gejala sistemik seperti demam, nyeri sendi, nyeri otot, dan gejala lainnya. Juga bisa terjadi agregasi trombosit yang menyebabkan trombosito- penia ringan. ${ }^{5}$

Trombosit berdiameter 2-5 $\mu \mathrm{m}$, ketebalan $0,5 \mu \mathrm{m}$, dan volume rata-rata sel 6-10 fl. Ukuran yang berbeda tidak memengaruhi fungsi trombosit. Umumnya masa hidup trombosit sekitar 7-10 hari. Trombosit berperan penting dalam hemostasis yaitu pembentukan dan stabilisasi sumbat trombosit. Proses pembentukan sumbat trombosit melalui beberapa tahap seperti adhesi trombosit, agregasi trombosit, dan reaksi pelepasan. ${ }^{6}$

Trombosit dihasilkan dalam sumsum tulang melalui fragmentasi sitoplasma megakariosit. Megakariosit mengalami pematangan dengan replikasi inti endomitotik yang sinkron, memperbesar volume sitoplasma sejalan dengan penambahan lobus menjadi kelipatan duanya. Pada berbagai stadium dalam perkembangannya, sitoplasma menjadi granular dan trombosit dilepaskan. Produksi trombosit mengikuti pembentukan mikrovaskuler dalam sitoplasma sel yang menyatu yang membentuk pembentukan mikrovaskuler dalam sitoplasma sel yag menyatu membentuk membran pembatas trombosit. Tiap megakariosit bertanggung jawab untuk menghasilkan sekitar 4000 trombosit. Interval waktu semenjak difensiasi sel induk manusia sampai bahkan produksi trombosit berkiasar sekitar 10 hari. Jumlah trombosit normal adalah sekitar 250 x 10\% $/ \mathrm{L}$ dan lama hidup trombosit yang normal adalah 7-10 hari. ${ }^{6}$

Fungsi utama trombosit adalah membentuk sumbat mekanis yang merupakan respon hemostasis normal terhadap cedera vaskuler. Tanpa trombosit, dapat terjadi kebocoran spontan darah melalui pembuluh halus. ${ }^{7}$

Mean Platelet Volume (MPV) dan Platelet Distribution Width (PDW) sudah mulai dikenal sejak tahun 1970-an dan sekarang mulai masuk dalam pemeriksaan rutin, namun belum masuk dalam kriteria mendiagnosis demam berdarah dengue. Nilai normal untuk MPV $7 \mu \mathrm{m}^{3}-10,5 \mu \mathrm{m}^{3}$ dan PDW 11\% - 18\%. ${ }^{8}$

Pemeriksaan serologi dikerjakan dalam mendeteksi infeksi virus dengue. Terdapat 
beberapa metode pemeriksaan laboratorium seperti antibodi spesifik yaitu IgG/IgM dan nonstructural protein 1 (NS1). Baku emas biasanya merupakan kombinasi dari kedua metode tersebut. ${ }^{2,9}$

Pemeriksaan penunjang lain yang sering dilakukan ialah uji untuk mengenali antibodi spesifik virus dengue baik immunoglobulin $\mathrm{M}$ (IgM) anti dengue infeksi dengue primer maupun immnuglobulin G (IgG) untuk diagnosis infeksi sekunder. Pemeriksaan serologis antibody IgM anti dengue ataupun IgG anti dengue akan mempertajam diagnosis DBD. Pada Infeksi primer Ig-M anti dengue akan muncul lebih dahulu daripada IgG dan biasanya terdeteksi pada hari ke-5 dan menurun dalam 1-2 bulan. Pada infeksi sekunder igG anti dengue akan cepat meninggi. ${ }^{9}$

\section{METODE PENELITIAN}

Penelitian ini menggunakkan desain potong lintang. Penelitian ini dilaksanakan di pada Bulan Desember 2014 sampai Januari 2015.

\section{HASIL PENELITIAN DAN BAHASAN}

Sesuai dengan hasil penelitian di Bagian Pediatri RSAD Robert Wolter Mongisidi, RS Advent Manado, RS Pancaran Kasih GMIM terdapat 37 orang anak yang terinfeksi virus dengue dengan 20 orang anak perempuan (54,1\%) dan 17 orang anak plaki-laki (45,9\%). Hasil ini serupa dengan penelitian Bagian Pediatri di RS Andalas yang menunjukkan bahwa pasien perempuan $(52,51 \%)$ lebih banyak dari laki-laki (47,49\%).

Berdasarkan penelitian menurut kelompok umur, dapat dilihat bahwa kelompok umur $<1$ tahun 1 orang $(2,7 \%)$; 1-4 tahun 6 orang (16,2\%); dan 5-14 tahun sebanyak 30 orang (81,1\%). Berbeda dengan penelitian menurut Syofi Nelli $^{10}$ yang mendapatkan jumlah penderita anak DBD laki-laki 47 orang atau 50,0\% dan pada perempuan 47 orang atau 50,0\%, dengan perbandingan antara anak laki-laki dan perempuan 1:1. Sumarmo et al. ${ }^{10}$ melaporkan perbandingan antara jumlah penderita anak laki-laki dan perempuan $1: 1,3$. Hasil penelitian di Vietnam (2005) ${ }^{10}$ terhadap bayi melaporkan terdapat perbandingan antara jumlah penderita anak laki-laki dan perempuan 1,29:1. Dari hasil perbandingan di atas dapat dilihat bahwa jenis kelamin yang lebih banyak terserang infeksi dengue belum jelas.

Pada hasil pemeriksaan laboratorium yang dilakukan dari 37 sampel yang didapat 59,5\% positif NS-1, 37,8\% positif IgG, dan 2,7\% positig IgM. Pemeriksaan ini dilakukan dengan tujuan untuk mendeteksi dini apakah seseorang terkena infeksi dengue atau tidak. Terdapat 37,8\% yang positif terdeteksi NS-1 artinya anak tersebut dibawa ke rumah sakit oleh orang tuanya saat masih awal fase demam yaitu antara 1-3 hari. Pada fase awal demam sensitivitas NS-1 sangat tinggi bahkan bisa sampai $100 \%$, namun dapat turun di hari sesudahnya. ${ }^{11}$ Disini juga dapat ditemukan jumlah kasus positif IgG dan IgM yaitu satu orang $(2,7 \%)$ yang positif IgM; hal ini menandakan suatu infeksi primer virus dengue. Sejumlah $37,7 \%$ (14 orang) terkena infeksi sekunder.

Terdapat 21 (56,8\%) yang mengalami penurunan trombosit (trombositopenia), sedangkan $16 \quad(43,2 \%)$ mempunyai trombosit masih dalam jumlah normal. Hasil penelitian Shah et al. di Bangladesh menunjukkan dari 100 penderita anak-anak yang positif infeksi dengue pada DBD dan DSS, 52 (61,7\%) menunjukkan trombositopenia. Adanya trombositopenia dan rendahnya jumlah trombosit pada saat sakit akan membantu diagnosis DBD dan berkorelasi positif dengan keparahan penderita DBD. ${ }^{10}$

Nilai PDW dan MPV dalam penelitian ini menunjukkan nilai normal. Berbeda dengan penelitian yang dilakukan Gunawan et al. ${ }^{12}$ yang menunjukkan adanya perbedaan yang signifikan.

Berdasarkan penelitian menurut kelompok umur, dapat dilihat bahwa kelompok umur kurang dari satu tahun sejumlah 1 orang (2,7\%), 1-4 tahun 6 orang (16,2\%), dan 5-14 tahun sebanyak 30 orang $(81,1 \%)$. Berdasarkan pembagian ini dapat 
dilihat anak-anak dengan kelompok umur 5-14 tahun merupakan yang terbanyak terserang infeksi virus dengue. Hasil ini sama dengan penelitian Raihan et al. ${ }^{13}$ yang melaporkan bahwa umur rentan terserang DBD alah 5-14 tahun. Umur juga berpengaruh dalam derajat keparahan yang dimiliki pasien. Peneliti lain mendapatkan bahwa kerentanan untuk terjadi syok relatif konstan antara umur 4 - 12 tahun dan menurun pada usia remaja. ${ }^{13}$

Hasil penelitian ini juga menunjukkan bahwa Manado merupakan daerah tempat tinggal yang banyak ditemukan kasus DBD, diikuti daerah Minahasa dan Bitung.

Distribusi pasien berdasarkan status IMT yang terbanyak ialah pasien dengan IMT normal sebanyak 27 orang (73,0\%); kurus sebanyak 7 orang $(18,9 \%)$, dan gemuk sebanyak 3 orang $(8,1 \%)$. Hal ini berbeda dengan penelitian Hakim dimana disimpulkan bahwa pasien dengan gizi buruk lebih rentan terinfeksi dengue dibandingkan dengan pasien normal. Selain faktor gizi, faktor lingkungan seperti curah hujan dan faktor perilaku juga turut berperan dalam meningkatkan penularan infeksi dengue.

Berdasarkan lamanya demam pasien saat masuk rumah sakit didapatkan hasil terbanyak pada hari ke-3 sebanyak 21 orang (56,8\%), hari ke-4 sebanyak 9 orang (24,3\%), dan hari ke-5 sebanyak 7 orang $(18,9 \%)$. Jumlah pasien yang terdeteksi dengan menggunakan NS1 sebanyak 23 orang (62,2\%). Hasil ini sesuai dengan teori yang mengatakan bahwa puncak kadar NS1 anti-dengue didapatkan pada hari ketiga demam dan kadarnya akan menurun setelah hari kelima. ${ }^{11}$

\section{SIMPULAN}

Berdasarkan hasil penelitian yang dilakukan di Bagian Pediatri RSAD Robert Wolter Mongisidi Manado, RS Pancaran Kasih GMIM Manado, dan RS Advent Manado, dapat disimpulkan bahwa sebagian besar anak yang terinfeksi virud dengue menunjukkan penurunan jumlah trombosit.

\section{DAFTAR PUSTAKA}

1. Hadinegoro SR, Moedjito I, Chairulfatah A. Pedoman Diagnosis dan Tata Laksana Infeksi Virus Dengue pada Anak (Edisi ke-1). Jakarta: UKK Infeksi dan Penyakit Tropis Ikatan Dokter Anak Indonesia, 2014; p.1.

2. Purnama Dewi NLS, Wirawati IAP. Peranan Pemeriksaan Serologi pada Infeksi Virus Dengue. Denpasar: Bagian/SMF Ilmu Patologi Klinik Kedokteran Universitas Udayana, 2014.

3. Rampengan TH. Demam Berdarah Dengue dan Sindrom Syok Dengue. In: Rusmi, editor. Penyakit Infeksi Tropik pada Anak (Edisi ke-2). Jakarta: EGC, 2007; p.122.

4. Valentino B. Hubungan Antara Hasil Pemeriksaan Darah Lengkap dengan Derajat Klinik Infeksi Dengue pada Pasien Dewasa di RSUP Dr. Kariadi Semarang (KTI Strata 1). Semarang: Program Pendidikan Dokter Fakultas Kedokteran Diponegoro, 2012.

5. Frans EH. Patogenesis Infeksi Virus Dengue. Surabaya: Fakultas Kedokteran Universitas Wijaya Kusuma, 2012.

6. White JG. Platelet strucuture. In: Michelson AD, editor. Platelets (Edisi ke-2). USA: Elsevier, 2007; p. 45-73.

7. Hoffbrand AV, Moss PAH. Trombosit, koagulasi darah, dan hemostasis. In: Kapita Selekta Hematologi (Edisi ke-6). Jakarta: EGC, 2013; p. 293-8.

8. Leal-Santos F, et al. Altered platelet indices of potential markers of severe and complicated malaria caused $\mathrm{y}$ plasmodium vivax. Malarial Journal. 2013;12(462):1-6.

9. Arhana BNP. Rasio IgG dan IgM untuk mengetahui infeksi dengue. Sari Pediatri. 2006;8(1):2-8.

10. Sutirta-Yasa IWP, Putra GAET, Rahmawati A. Trombositopenia pada demam berdarah dengue. Medicina. 2012;43(2):114-21.

11. Mitayani. Peranan Antigen NS1 dalam Penanganan Diagnosa Demam Dengue di Indonesia. Syifa' Medika. 2011;1(2):76-82.

12. Gunawan S, Sutanto FC, Tatura SNN, Mantik MFJ. Platelet Distribution Width dan Mean Platelet Volume. Hubungan dengan derajat demam 
Jurnal e-Biomedik (eBm), Volume 3, Nomor 2, Mei-Agustus 2015

berdarah dengue. Sari Pediatri. 2010;12(2):74-7.

13. Raihan, Hadinegoro SHS, Tumbelaka
AR. Faktor Prognosis Terjadinya Syok pada Demam Berdarah Dengue. Sari Pediatri. 2010;12(1):47-52. 